\title{
A Review of Cogent Reflection on the Economic Impact Assessment of Conferences - MICE Tourism
}

\author{
J. Kumar ${ }^{1}$, K. Hussain ${ }^{2}$, F. Ali $^{3}$ \\ ${ }^{1,2}$ Hospitality, Tourism and Culinary Arts, Taylor's University, 47500 Subang Jaya, Selangor, \\ Malaysia \\ ${ }^{3}$ International Business School, Universiti Teknologi Malaysia, 54100 Kuala Lumpur, Malaysia
}

\begin{abstract}
MICE tourism has g rown into an impor tant economic sector in many places, and it is quite easy to understand the relevancy of estimating the economic impact of business tourists on the local an $\mathrm{d}$ regional economies. Several indus trial and academic researches has mentioned many methods for economic impact studies (direct, indirect and induced impacts) of the conference - MICE $t$ ourism related events. Of these, the inputoutput (I-O) model and general equilibrium models (REMI and REM II) are widely used for the economic impact assessments. The current paper will $\mathrm{r}$ eview economic impact studies in the c conference - MICE tourism related events and then discusses the issues related to the I-O model and general equilibrium models framework
\end{abstract}

\section{Introduction}

MICE tourism has become an important economic sector in many parts of the world and developed as very important in modern global market, also known as meeting, incentives, conventions and exhibitions (MICE) sector [1,28] meeting industry [2]. To evaluate the contribution conferences to an area is to assess this activity through an input-output model and general equilibrium models such as REM I and R EM II. All models can be used to determine the economic impacts of an activity to a region. Any type of economic impact study, economic impact analysis confirms that final demand will be if conference delegates did not get all facilities.

According to [3], there are s everal social and cultural benefits are related with conferences and MICE tourism for the hosting destination, such as;

- Augmentation of exchange commutation of ideas and information,

- Adoptive business connections

- Forums s for continuing education and training

- Technology adoption

Further, conferences venue and the hosing destination can also give chance to showcase their skills

and capabilities to attract fu ture mega events to the destination, and to build up good sense of excitement, community, pride and coherence [4]. 
The economic impact of confe rence and MICE tourism is well syste matized in the academic research, trade journals and in dustry reports. This activity of the res earch on economic impact assessment results into better understanding conference - MICE tourism and their impact on the host destination.

Previously, data on the economic impact of conference - MICE tourism are often incomplete and limited, therefore the worth an d value of the conference - M ICE tourism was un derestimated or overestimated [5-7]. Because of this shortcoming in extant industry data, a number of recent academic studies report have focused on creating theoretically sound frameworks, audio fabric, particularly input-output (I-O) models, example, for estimating the total contributions of conventions and special events to host conventionality and special events to innkeeper destinations.

Though, some of the researchers [8-10] raised the question on the validity of the input - output approach in measuring the economic impact for particular conference. Crompton et al. [8] stated that despite adherence to the basic principles of economic impact analysis, the resulting impacts remain a best guess. This article will rev iew the extant research on assessing the economic impact of conferences - MICE tourism.

\section{Literature Review}

\subsection{Economic Impact Assessment}

MICE industry has outstanding indirect and induced impacts. An easy way to summarise all these three impacts as, money spend by tourists, participants, delegates in the restaurants, hotels of in any of the tourism products can be referred as direct effect. Restaurants also use to buy products suc $h$ as vegetables and other ingredients form other businesses, which can be called as indirect effect. Induced effect get occurs due to additional income of the restaurants and hotel employee and they s pend money in the local economy by purchasing goods and services [28-29].

Economic impact studies are very much beneficial because they illustrate the benefits of travel and tourism, several studies for economic i mpacts assessment are been done and vary in methodological part or the information level gathered. That is one reason which makes each and every study different. There are different factors for the economic impacts studies like the tourism industry always study and show the positive economic impacts of the tourism but on other hand local residents always come up with the negative economic impacts of the business tourism [30].

In general an economic impact analysis of the MICE industry focuses on the increase in sales, income and the $\mathrm{j}$ ob opportunities in the local economy (area, region) resulting from the tourism practices. [35] mentioned in report 'The value of business events' for Tourism \& Business Events International for Joint Meetings Industry Council, that benefits for assessing business events can be described in two parts;

- Return on investment for delegates and their employers

- $\quad$ Other delegate and host destination benefits

The return on investment (ROI) is very well known procedure and used by many industries including business events, helps to estimate all the benefits for delegates (attendees) and their employers. Second ROI also estimates the benefits for the host destination for hosting and inviting a big number of delegates to attend and participate in the event.

\subsection{Economic Impact Assessment Models}

In the literature on economic impact assessment in tourism - business tourism or other events, there are several models has been discussed. Economic impact assessment cost can range from $\$ 500$ to $\$$ 50,000 or more. Cost depends on the size and scope of the study being covered in the research, size of 
study region, how much the primary data are to be collected. $[28,31]$ mentioned that several models can be di vided by 52 potential criteria and su bdivided into 10 groups. Groups of criteria can be identified; Efficiency, Data used as input into models, Comparability - standardization, Transparency and simplicity, Trust in the models - validation and familiarity, Sensitivity in the analysis, underlying analyses, Expenditure categories, Output indicators, Externalities [1, 28, 32-33].

\subsection{Economic Impact Assessment of Conferences - MCIE tourism}

The strength of an economic impact study is that it provides results and advices to policy- makers, local planners, and investors to which are easily interpretable to make decision for future development for the host destination. $T$ he results play a $\mathrm{cr}$ itical role in public policy and pri vate decisions. However, the results are dependent on an objective assessment appraisal of an event's impact on a host community.

In last two decades, the growth of the conference - MICE industry has created an awareness of the economic importance of conferences to the local, state, and national economies. Res earchers, from both industrial and academic, confirmed that conferences - MICE tourism is one of the key contributor to regional and national economies [11-12, 28].

Though, many researchers have also argued that the existing industry data and statistics on the economic impact of MICE tourism has been underestimated for several reasons, such as;

- Published f gures provide only national totals and regional impacts of MICE tourism are missing [13].

- Tracking total convention spending by delegates, sponsors, or exhibitors is diff cult [14].

- Published data almost always fail to distinguish conferences from trade shows, expositions, incentive travels, and other types of meetings, which makes it diff cult to gauge the exact inf uence of conventions on the host community $[11,15]$.

- Reported data often underestimate the fact that nearly 70 pe rcent of conference delegates combine business and family leisure

$\bullet$

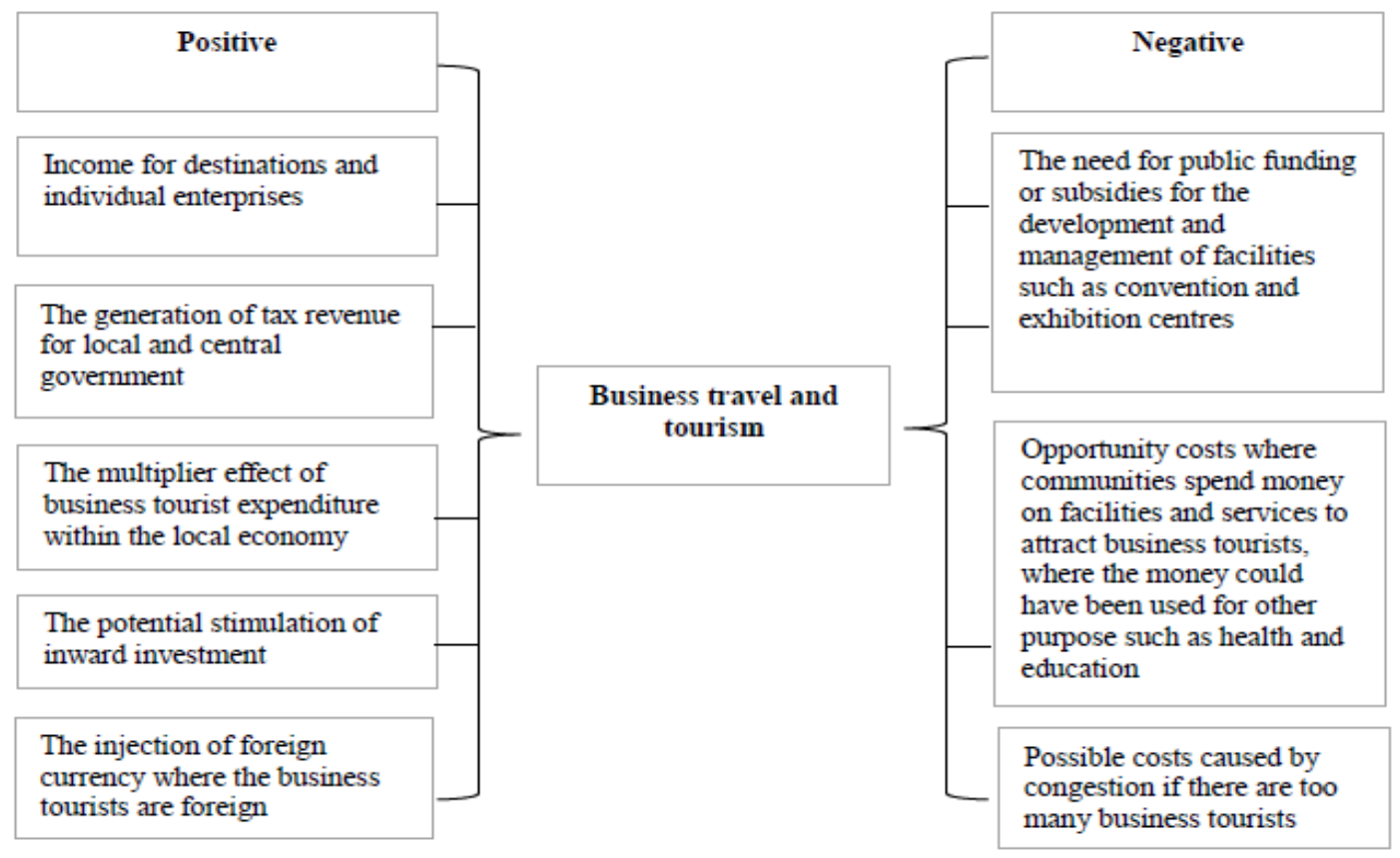

Figure 1. The Economic Impacts of Business Tourism on a Local Economy [34] 
A study done by [5] stated national and state information for local analysis and very first time used multipliers and linked with industry method to estimate the economic impact of conventions on Florida. He identified 32 sectors in calculating the total impact.

Later, [14] pointed out that the results of [5] study may produce inflated figures in the regional I-O model of convention spending because some sectors included in Braun's model, such as banking, legal services, insurances services, warehousing, and trucking, were not likely to be heavily affected by convention spending.

[15-16], matched the economic impact of MICE tourism on overall travel and tourism activity in a nine-county rural region. The results of their study indicates that in 2001, the total expenditure of international delegates and convention hosts was app roximately $\$ 130.4$ million. These convention receipts generated $\$ 217.3$ million in to tal output, 13,702 in full-time jobs, \$47.4millioninresidents'personalincomes, \$114.6millionvalue added, and \$11.9 million in taxes. Also, using the data on expenditures of the convention and exhibition industry in Australia, [3] presented a framework for estimating the economic impact of the convention sector on gateway and rem ote locations.

\subsection{Industry Data - Statistics}

Table 1. MICE Traveller's Spending

\begin{tabular}{|l|c|c|}
\hline Region & $\begin{array}{c}\text { Total MICE Traveller } \\
\text { Spending (US\$ billion) }\end{array}$ & $\begin{array}{c}\text { MICE Traveller Intensity (\% } \\
\text { GDP) }\end{array}$ \\
\hline America & 302 & 1.6 \\
\hline Europe & 290 & 1.5 \\
\hline Asia Pacific & 226 & 1.7 \\
\hline Middle East & 18 & 1.2 \\
\hline Africa & 21 & 1.5 \\
\hline World & 857 & 1.5 \\
\hline
\end{tabular}

(Source: [17])

World Travel and Tourism council (WTTC) mentioned in their busine ss travel report for the y ear 2011 that the total amount spent by business tourists was 857 US\$ billion which is $1.5 \%$ GDP of the overall world. As per [17], 145 million business tourists travelled worldwide in 2012. Specifically in Asia Pacific region the number of tourists travelled for business purpose in year 2012 was 61.74 million.

Among the many industry data, however, researchers most commonly cite the Convention Liaison Council (CLC) data (1995) and Meeting Market Report in Meetings and Conventions (2002). Hence CLC data states that MICE contributed $\$ 82.8$ billion to theU.S.economyin1994. The Meeting Market Report showed that in 2001, a to tal of 79,900, 000 MICE attende generated $\$ 93.6$ billion in expenditures.

Even though these industry data, questions have been raised about the validity of the economic impact studies [11,13-14,18-20]. According to [18], observations CLC data have not been updated since 1995 and, therefore, cannot be used in longitudinal analysis. Furthermore, the data did not provide the number of meetings held each year. Meeting Markets Report went further than CLC data in assessing attendance and expenditure for a10-year period [5]. Stated that each dollar of MICErelated spending initiates a broad set of economic interactions that produce additional spending in other sectors of a region's economy (Multiplier effect). Thus, the economic impact of MICE related spending could have double or triple effects due to its indirect influence on host city economies. Further, $[11,28]$ stated in their study that to overcome the shortcoming and difficulties in measuring the total economic impacts of the MICE tourism industry, the researchers should interpret the existing estimates of the size of the industry with proper attention. 


\subsection{Input - Output Models}

Input-output (I-O) an alysis is a frequ ently used tool to evaluate economic impacts from tourism [10,20-21]. IO analysis deal s with the empirical study of the $\mathrm{i}$ nterdependence among the various sectors of an economic area-nation, region, state, etc. It shows the uses of the output from each sector or industry as an input to other industries/sectors in the economy. Vast literature exists on I-O models, such formulations are based primarily on the pioneering work by [21].

As per [22], the essential underlying relationship of the input-output model is that the amount of product (goods or services) produced by a given sector in the economy is determined by the amount of that product that is purc hased by all the users of the product. Simply, each sector uses some of the output of other sectors to produce a product. Thus, the I-O model provides estimates of the degrees of interdependence among industrial sectors and catalogues the sales and purchases made by different sectors of economy [15].

Input-output models connects several i ndustries with each other related to their activities. Therefore, a change in one industry can be notified through all the related industries. Input-output models use financial flow data gene rated from businesses' accounts, and spe nding patterns for households of particular income levels, to describe the economic linkages that exist within a regional economy. Input-output models offer only before and after scenario of the conference - M ICE industry. $[10,28]$ stated several benefits of I-O model for using in economic impact studies such as;

- Provides policymakers with a comprehensive view of the economy

- It focuses attention on the sectorial interdependence that exists in the economy

- The flexibility of the I-O model enables researchers to construct a model to suit the purpose of a study

- The nature of the I-O model makes the technique policy neutral because each sector is treated in a uniform manner

Further, Fletcher [10] strongly supported the use of the I-O model for economic impact studies in tourism research because the disaggregated model recognizes the different production characteristics of each industry, such as transp ortation, accommodation, food and be verage, and entertainment. The shortcomings of the existing data on the economic size of the conference - MICE industry provide motivation for researchers in MICE related economic studies to use the I-O fram ework in estimating the true economic impact of conventions and events.

\subsection{General Equilibrium Models}

General equilibrium models syndicates the sector detail and geography detail of input/output models but provide for functioning economic linkages between sectors and regions overtime. REM I and II models are also a type of ready-made models, REM I was developed by Regional Economic Models, Inc. This model is not only econometric model; it can be defined as an electric model [24].

Because this model links input output model to an econometric models. If the econometric models are not working well or go down, the model collapses to the input output model. This model is nonsurvey based and need information from national technical coefficients. The model is static so cannot estimate the time path of economic impacts.

REM II model is designed and maintained by US Department of Commerce/ Bureau of Economic Analysis. It helps users with five type of multipliers such as, final demand multipliers for output, for earnings, for employment and direct effect multipliers for earnings and employment. For effective use of REM II model, the geographically and industrially information is required and it is static model which cannot help to forecast the economic impact for any of the region.

A leading general equilibrium model is REMI includes the basic input/ output linkages, but also uses econometrically estimated county specific $\mathrm{p}$ arameters such as inter regional migration in response to changes in economic opportunities in generating impacts results. 
Changes in spending in a region affect not just conditions in that market, but also in other markets within the region and outside the region.

These are the general equilibrium properties of the model. REMI also simulates the adjustment path over time of these market responses using historical parameters. The larger the spending flow, the greater the value of a Com putable General Equilibrium Model, as the effect on the labour force and prevailing wage rate could be significant and have ripple effects throughout the local economy.

\section{Discussion}

The current study on the economic impact of conference - MICE tourism discloses that most of the recent studies on economic impacts of MICE tourism has provided theoretical formwork by using I-O models and some with general equilibrium model. Several studies has fo cused on the economic benefits for the destination hosting the conference-MICE event. Benefits includes direct, indirect and induced effects (increase in income, job opportunities and the tax receipt).

There are also few rec urrent errors a re also discussed while using I-O model for the economic impact studies, such as;

- Using incremental rather than true multipliers

- Using sales rather than income multipliers

- Biasing employment multipliers

- Including local residents

- $\quad$ No time Tack

According to [25], the I-O model could have problems due to few basic rules such as;

- I-O analysis assumes constant returns to scale

- Each industry is assumed to produce only one type of product

- Each product within the industry is assumed to be the same

- Technical coefficients are assumed to be fixed

- No constraints on resources are assumed

Further, $[10,28]$ stated that each of the above key ass umptions can have severe problem in economic impact studies.

Another question about the validity of many economic impact studies is related to the sampling variability: recipients (hoteliers, restaurateurs, retailers, etc.) or sp enders (visitors, organizational bodies, etc.). Many economic impact studies in tourism have tended to rely on surveys of spenders, particularly visitors [26]. Similarly, economic impact studies in convention and event tourism have commonly tended to estimate directly the expenditures associated with co nvention attendees and tourists who are attracted by the event. How- ever, care must be taken; expenditures that would not have occurred in the absence of the convention and event are difficult to measure $[26,19]$.

Second problem in most of the economic studies was regarding the validity and sampling variability. As most of the tourism economic impacts studies usually rely on conduct surveys with the spenders such s confere nce delegates, therefore it is very hard to measure the delegates spending which is been spend in the absence of the conference - MICE event [19, 26].

Tyrrell and Johnston [19] came up with the assessment framework that can be helpful to distinguish gross economic impact from net economic impact regarding;

- The source of the expenditure

- The geographic origin of the expenditure

- The end point of the expenditure

- The causes of the expenditure 
Few studies also raised question regarding choice of economic variables in the economic impact of conferences - MICE tourism. Particularly, using em ployment multipliers is problematic because conferences - MICE tourism are short term events; therefore, it is d ifficult to create full time jobs [26].

Finally, all eco nomic impact studies have their limitations. Quality data is often difficult or expensive to achieve. Data limitations will affect the accuracy of the study, but the benefit of $\mathrm{m}$ ore accurate data must be considered against the cost of its attainment.

\section{Conclusion}

MICE tourism has grown int o an important economic sector in many places, and it is quite easy to understand the relevancy of estimating the economic impact of business tourists on the local and regional economies. Economic impact studies play a critical role in assessing the potential benefits for the host of MICE events. This paper acknowledges the conferences impact and problems could occur to conduct studies for conference - MICE events and usage of I-O model.

However, academically appropriate I-O models can provide ambiguous results if certain issues are not carefully addressed while conducting the economic impact study; inherent assumptions, sampling variability, expenditure switching and the choice of economic variables. Future economic impact studies should be more conceptually sound frameworks keeping a proper check on all these concerns, and these frameworks require a more accurate and inclusive data set. A better understanding of the economic impact of conference - MICE events on host destinations has always been needed to create an accurate da ta base for the conference organizer and the host destinat ion. In particular, accurate measures of confere nce delegates and their expenditures directly attributable to conference would allow policymakers to more accurately estimate the economic impact of the conference - MICE event and make more informed decisions.

Some recommendations are made to minimize project delays in private housing projects. The recommendations are:

1. Proper planning before commencement of the project.

2. Approval and confirmation of the design concept, construction drawings, material selection, logistics planning, etc., prior to construction.

3. Improvement in communications, e.g. regular and fruitful meetings and site visits with the relevant parties in order to solve problems in time.

4. Effective control and monitoring of site workers to improve productivity.

5. New rules and regulations should be relayed to the developers / contractors as soon as possible so that the developers /contractors are aware of changes to the rules and regulations.

6. Client to stick to the original plan and to allocate an adequate budget for any contract modifications.

7. Site management and proper award on time are important to avoid project delays.

8. Close monitoring of the progress of work.

9. Counter-check the accuracy of data on the work-in-progress with the actual physical completion versus the cost expended.

10. Propose a "Bonus" scheme for early completion.

11. Effective planning and scheduling would overcome the problem.

The project management team (client \& consultants) should be more professional and responsible in handling their respective fields and not depend on the contractor to solve their problems, especially in matters involving the local authorities. Also, the client or the project team should minimise internal protocols or lengthy procedures for obtaining approvals and confirmation, which normally interrupt construction planning on the site. 


\section{References}

1. L. Dwyer, P. Forsyth. Impacts and benefits of MICE tourism: A framework for analysis, Tourism Economics, 3, 1,21-38 (1997)

2. UNWTO. Measuring the Economic Importance of the Meeting Industry: Developing a Tourism Satellite Account Extension. (Mardid: United Nation World Tourism Organization, 2006)

3. N. Mistilis, L. Dwyer. Tourism gateways and regional economies: The distributional impacts of MICE. I. J. of Tour. Res., 1, 6,441-457 (1999)

4. C. Lee, T. Taylor. Critical reflections on the economic impact assessment of a mega-event: The case of the 2002 FIFA World Cup. Tour. Manag, 26, 595-603(2005)

5. B.M. Braun, B. Rungeling. The relative economic impact of convention and tourist visitors on a regional economy: A case study, Int. J. of Hosp. Manag., 11, 1, 65-71 (1992)

6. E.T. Falk, A. Pizam. The United States' meetings market. I. J. of Hosp. Manag., 10, 2 (1991) $111-118$

7. S.L. Smith. Tourism analysis: A handbook. (New York, NY: Longman, 1989) Retrieved June 26, 2014 from http://www.successmtgs.com.

8. J.L. Crompton, S. Lee, T.J. Shuster. A guide for undertaking economic impact studies: The Spring fest example. J. of Travel Res., 40, 1, 79-87 (2001)

9. J.L. Crompton, S.L. McKay. Measuring the economic impact of festivals and events: Some myths, misapplications and ethical dilemmas, Fes. Manag. \& Event Tour, 2, 1, 33-43 (1994)

10. J.E. Fletcher. Input-Output analysis and tourism impact studies. Ann. of Tour. Res., 16, 4, 514-529 (1989)

11. G.I. Crouch, J.R. Ritchie. Convention site selection research: A review, conceptual model, and propositional framework, J. of Coven. \& Exhibit. Manag, 1, 1, 49-69 (1988)

12. D.G. Rutherford, L.A. Kreck. Conventions and tourism: Financial add-on or myth? Report of a study in one state. J. of Travel \& Tour. Mark, 3, 1, 49-63 (1994)

13. W. Zelinsky. Convention land USA: The geography of a latterday phenomenon. Ann. of the Assoc. of American Geographers, 84, 1, 68-86 (1994)

14. S. S. Kim, K. Chon, K. Chung. Convention industry in South Korea: An economic impact analysis. Tour. Manag, 24, 5, 533-541 (2003)

15. G.G. Fenich. Convention center operating characteristics. J. of Coven. \& Exhibit. Manag, 1, 2/3, 1-25 (1998)

16. S.C. Grado, C.H. Strauss, B.E. Load. Economic impacts of conferences and conventions. J. of convent. \& Exhibit. Manag, 1, 1, 19-33 (1998)

17. World Tourism and Travel Corporation. Bu siness Travel: A Catalyst fo $\mathrm{r}$ Economic Performance. (London: World Tour and Travel Council, 2011).

18. G.G. Fenich. Towards a conceptual framework for assessing community attractiveness for conventions. J. of convent. \& Exhibit. Manag, 3, 1, 45-64 (2001)

19. T. Tyrrell, R. Johnston. A framework for assessing direct economic impacts of tourist events: Distinguishing origins, destinations, and causes of expenditures. J. of Travel Res., 40, 1, 94$100(2001)$

20. W. Leontief. The Structure of American Economy, 1919-1939. (New York: Oxford University Press, 1951)

21. W. Leontief. Quantitative input and output relations in the economic system of the United States. The Review of Economic Statistics, 18, 3, 105-125 (1936)

22. D.S. Rickman, R.K. Schwer. A Comparison of the Multipliers of IMPLAN, REMI and REM II: Benchmarking Ready Made Models for Comparison. Regional Science, 29, 4, 363 -374 (1995)

23. Organization for Economic Co-operation and Development. Structural change and industrial performance. (Paris: OECD Publishing, 1992) 
24. B. Burgan, T. Mules. Economic impact of sporting events, Ann. of Tour. Res., 19, 4, 700710 (1992)

25. H. Briassoulis. Methodological issues tourism input-output analysis, Ann. of Tour. Res., 18, 485-495 (1991)

26. R.L. Johnson, E. Moo re. Tourism Impact Estimation. Ann. of Tour. Res., 20, 2, 279-288 (1993)

27. UNWTO. Tourism Highlights: Facts and Figures. (Mardid: United Nation World Tourism Organization, 2013)

28. J. Kumar, K. Hussain. Estimating the economic impact of business tourism: a revi ew of issues and methods. In Nair, V., Hussain, K., Mura, P., Hui, K.H.K., Ragavan, N.A. (Eds). Breaking Barriers - Shifting Gears - Proceedings of the 12th APacCHRIE Conference 2014, Kuala Lumpur, Malaysia: Taylors University (2014)

29. H. Vogelsong, A. R. Grae fe. Economic Impact Analysis: A Look at useful Methods. P \& R Mag., 3, 1, 28-36(2001)

30. W. R. Fleming, L. Toepper. Economic Impact Studies: Relating The Positive And Negative Impacts To Tourism Development. J. of Travel Res, 29, 1, 35-42 (1990)

31. J. Klijs, W. Heijman, D.K. Maris, J. Bry on. Criteria for comparing economic impact models of tourism, Tour. Eco., 18, 6, 1175-1202 (2012)

32. A. Blake, R. Durbarry, M. Sin clair G. \& Sugiyarto. Modelling tourism and travel using tourism satellite accounts and tourism policy and forecasting models', TTRI Disc ussion Papers (2001). (http://www.nottingham.ac.uk/ttri/discussion/2001 4.PDF).

33. L. Dwyer, P. Forsyth \& R. Spurr. Evaluating tourism's economic effects: new and old approaches, Tour. Manag, 25, 3, 307-317 (2004)

34. J. Swarbrooke, S. Horner. Business Travel and Tourism. (Oxford: Butterworth Heinemann, 2001) 